TID-4500, UC- 35 , Nuclear Explosions Peaceful Applications

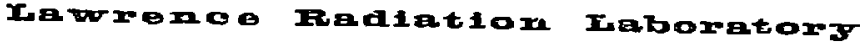 \\ UHIVERSITY OF EALIFORHIA \\ LIVERMBRE
}

$\mathrm{UCRL}-\mathbf{5 0 8 9 3}$

\title{
MICROFRACTURING IN POSTSHOT GASBUGGY CORE GB-3
}

\author{
I. Y. Borg
}

\begin{tabular}{|c|}
\hline 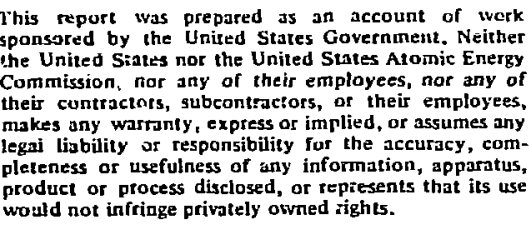 \\
\hline
\end{tabular}




\section{Contents}

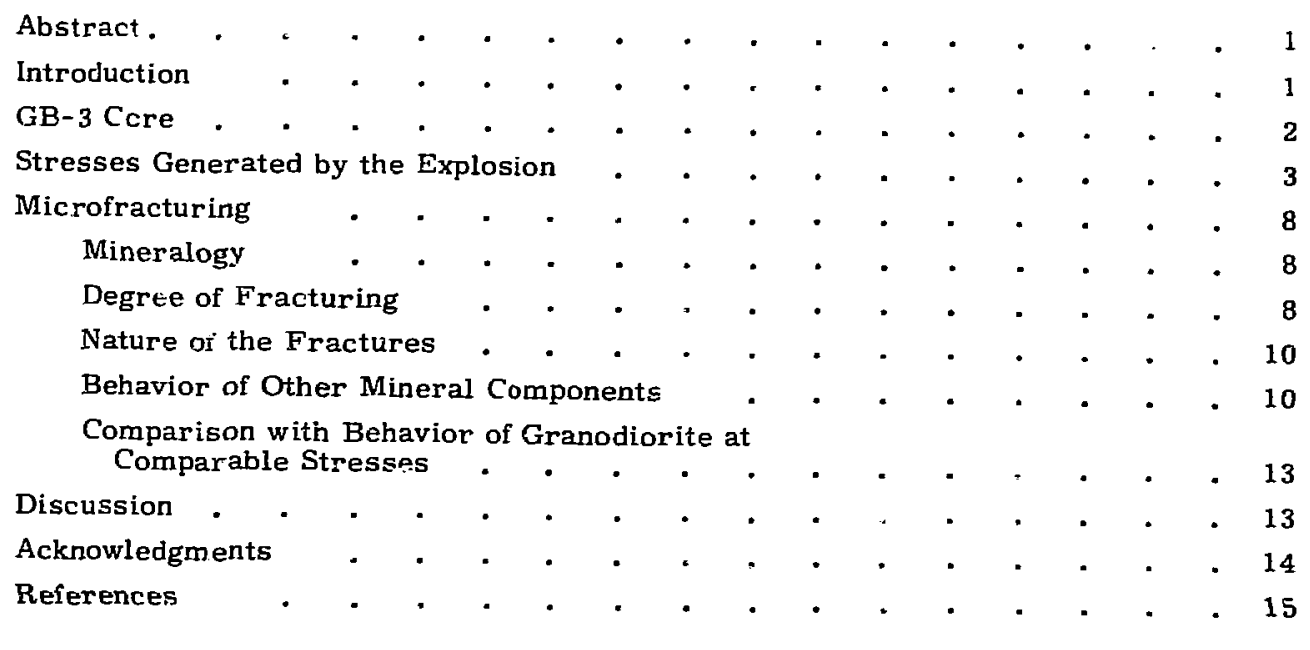




\title{
MICROFRACTURING IN POSTSHOT GASBUEGY CORE GB-3
}

\begin{abstract}
Microf racturing in the shocked rock of the Ojo Alamo, Picture Cliffs, and Lewis iormations has been examined microscopically in core samples. The amount of fracturing observed is small and shows little correlation with distance from che shot point, but it does show qualirative correlation with permeability measurements on the same cores. Fractures are: short-lived in the sandstones and term:nate within individual grains or die out in the semiductile cementing clays and micas. The finergrained sediments show extensive dilation on bedding and other compositional boundaries that results in open breaks ranging in width from less than $1 \mu$ to greater than $50 \mu$. At overburden pressure, it is questionable whether bedding dilations in fine, grained shales would appreciably increase the permeability over time intervals measured in years.

Calculated peak radial, tangential, and mean stresses for the core samples indicate that the m-ximum stresses seen by the rocks ar $:$ in the 6 to $8 \mathrm{~kb}$ range and are somewhat below the yield strengths of the rocks as measured in laboratory triaxial tests. Exact behavior of any rock below its ultimate strength is largely unknown, but it probably includes incipient fracture and ductility (slip or cataclastic flowl in the case of the transitional-type failure expected for Gasbuggy rocks. Comparisons of shock effects in brittle granodiorite and in the semibrittle Gasbuggy rocks at the same peak radial stresses indicate that matrix fracturing in the granodiorite is many times greater than that observed in Gasbuggy rocks. It points up the important role that weak cementing minerals in the Gasbuggy rocks have had in determining the mode of yielding of the whole.
\end{abstract}

\section{Introduction}

Project Gasbuggy was designed to determine to what extent an underground nuclear expiosion could stimulate gas flow. The experiment was conducted in an unproductive portion of a gas field within the San Juan Basin in New Mexico. General information concerning the pro- ject and the joint effort of participating agencies, including the $\mathrm{E}$.. Paso Natural Gas Company, the Bureau of Mines, the Urited States Department of the Interior, and the Lawrence Radiation Laboratory, has been summarized by Holzer ${ }^{1,2,3}$ ani Rawson et al. ${ }^{4}$ Some of the particulars 
relevant to the explosion are given in

Table 1.

The success of the experiment depends on the extent and magnitude of the changes in permeability in the gas-bearing strata surrounding the explosion. Hence, study of the nature and extent of fracturing on all scales is germane to the assessment of the experiment and to the interpretation of changes in permeability arù postshot production data. Fracturing on a gross scale was monitored by cliper cable and casing breaks. 5 Microfracturing has been studied in postshot cores GB-2RS and GB-3. ${ }^{6}$ The present report constitutes a resume of microfracturing as seen in samples taken from the GB-3 core.

Table 1. General data on the Gasbuggy Event.

\begin{tabular}{|c|c|c|c|}
\hline Date & December 10, 1967 & Radius of & $39 \mathrm{ft}$ (i $1.9 \mathrm{~m})^{8}$ \\
\hline Place & $\begin{array}{l}55 \mathrm{mi} \text { east of Farming- } \\
\text { ton, New Mexico }\end{array}$ & $\begin{array}{l}\text { vaporized and } \\
\text { melted rock }\end{array}$ & \\
\hline \multirow[t]{2}{*}{$\begin{array}{l}\text { Environment of } \\
\text { explosion }\end{array}$} & $\begin{array}{l}\text { Within Lewis shale, } \\
40 \mathrm{ft} \text { below the contact }\end{array}$ & $\begin{array}{l}\text { Chimney } \\
\text { height }\end{array}$ & $333 \mathrm{ft}(101.5 \mathrm{~m})^{5}$ \\
\hline & $\begin{array}{l}\text { with the gas-bearing } \\
\text { Picture Cliffs sand- }\end{array}$ & Apical void & None or small \\
\hline Yield & $\begin{array}{l}\text { stone. } \\
29 \pm 3 \mathrm{kt} \text { (from } \\
\text { evaluation of all effects) }\end{array}$ & $\begin{array}{l}\text { Time of } \\
\text { collapse }\end{array}$ & $30 \mathrm{sec}$ after detonation ${ }^{2}$ \\
\hline Depth of burst & $\begin{array}{l}4240 \mathrm{ft}(1292 \mathrm{~m}) \text { or } \\
2964 \mathrm{ft} \text { mean sea level }\end{array}$ & \multirow{2}{*}{$\begin{array}{l}\text { Overburden } \\
\text { pressure at } \\
\text { the working } \\
\text { point (W.P.) }\end{array}$} & \multirow[t]{2}{*}{$\sim 0.32 \mathrm{~kb}$} \\
\hline Cavity radius & $\begin{array}{l}84.6 \mathrm{ft}(25.8 \mathrm{~m})-\mathrm{SOC} \\
\text { calculation } \mathrm{GB}-22 \\
\text { based on } 25 \mathrm{kt} \text { yield; } 7 \\
80 \pm 2 \mathrm{ft}(24.4 \mathrm{~m})- \\
\text { from krypton concentra- } \\
\text { tions corrected for } \\
\text { porosity } 3\end{array}$ & & \\
\hline
\end{tabular}

\section{GB-3 Core}

The collar on the GB-3 hole was located 250 it NW of the top of the emplacement hole (1430 ft from south line and $1636 \mathrm{ft}$ from west line of Section 36 , T29N R4W, elevation $7200.4 \mathrm{ft}$ ) and was $4809 \mathrm{ft}$ long. Figure $I$ is a plot of distance from the working point (W. P.) as calculated from a Sperry-Sun Directional Sur- vey of the hols. The closest approach of the core to the W. P. is $197.6 \mathrm{ft}(50.2 \mathrm{~m})$ at $4243 \mathrm{ft}$ slant hole distance (SHD).

Specimens collected for study are listed in Table 2. Figure 2 is the stratigraphic column for the core as compiled by El Faso Natural Gas geologists. 6 


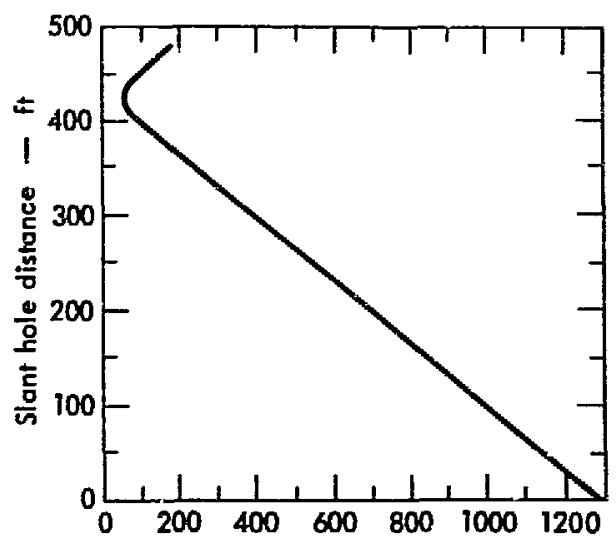

Radial distance to the working point - m

Fig. 1. Postshot radial distance from the shot point of core GB-3.

\section{Stresses Generated by the Explosion}

Some idea of the stress levels seen by the GB-3 rocks can be had from the SOC calculations of Cherry et al., ${ }^{2,9}$ which are based on a 25-ist yield. Peak radial, tangential, and mean pressure are given in Fig. 3 as a function of pre- and postshot radial distance. Calculated pormanent displacements are given in Fig. 4, and a plot of preshot vs postshot radial distances is shown in Fig. 5. The preshot positions and pressures seen by the core samples studied are tabulated in Table 2.

The maximum radial pressure experienced by the recovered core rocks is about $8 \mathrm{~kb}$ with a mean pressure of $6 \mathrm{~kb}$. At this point the stresses are close to the compressive strength of the Lewis shale as determined from laboratory triaxial tests (see Fig. 6). Higher up in core, within the Picture Cliff sandstone, the calculated stresses are somewhat below

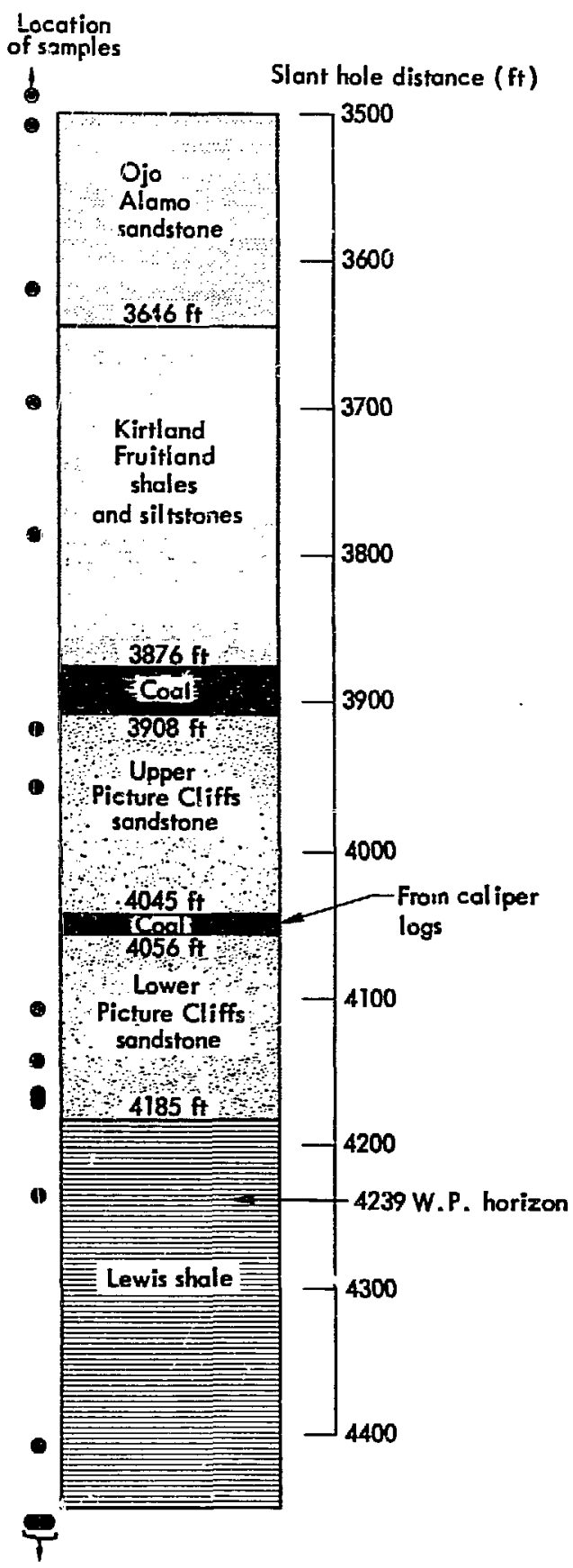

Fig. 2. Stratigraphic column from core GB-3.6 
Table 2. Description of Gasbuggy samples from Core GB-3.

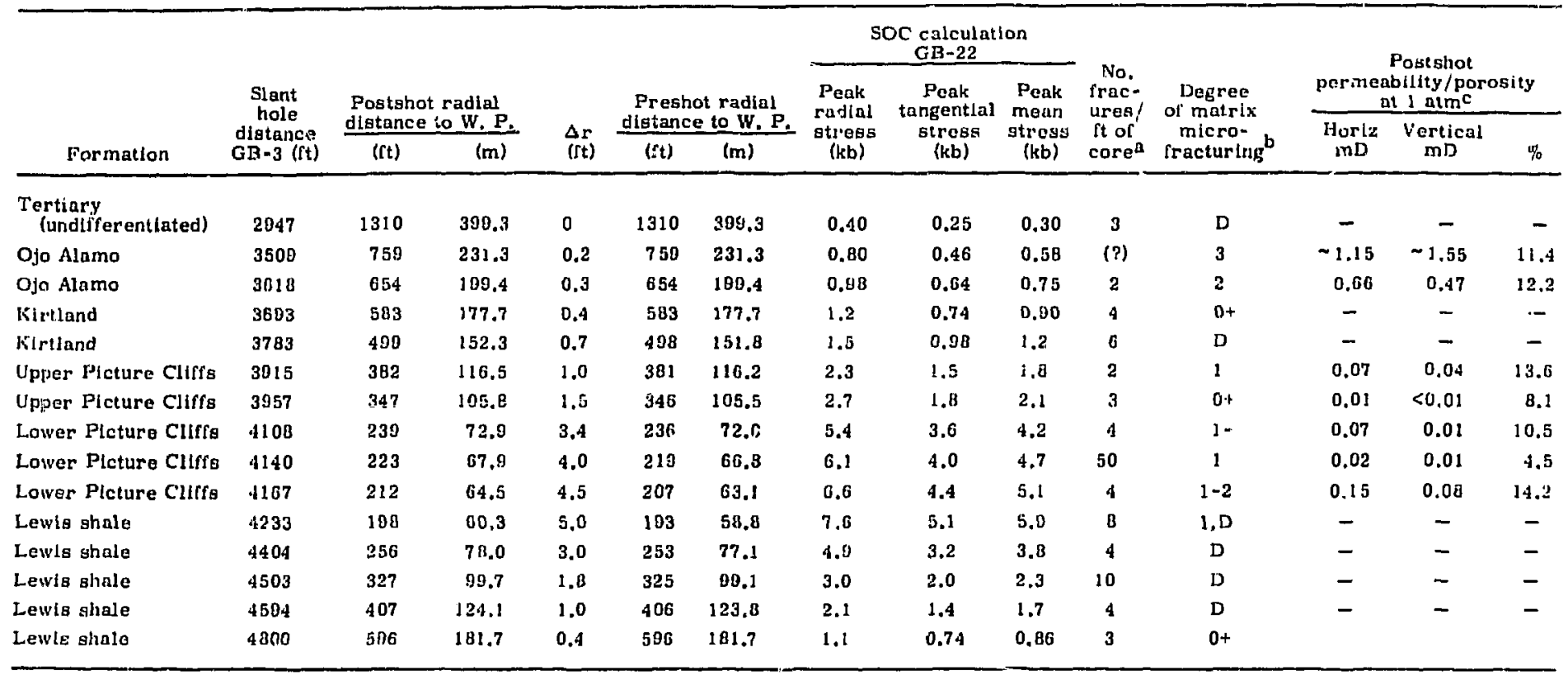

ase Ref. 6 ,

$\mathrm{b}_{0}$ - no fracturing: 1 - low: 2 - low-moderzte: 3-modertite: $D$-dllation on bedding.

${ }^{c}$ Core Laboratories, Inc, data courtesy El Puso Natural Gas Co. 


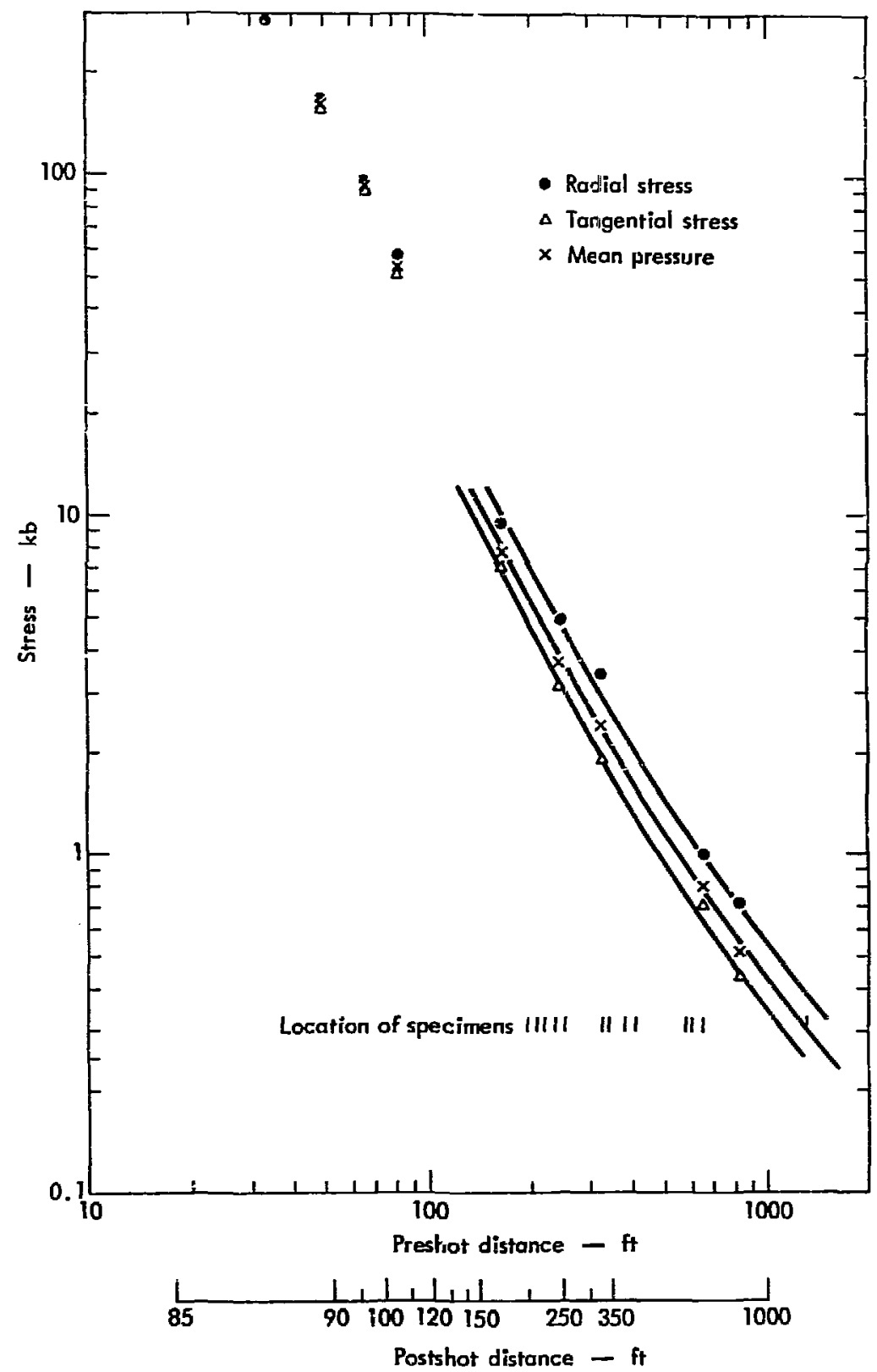

Fig. 3. Stresses as a function of distance from the shot point fer the Gasbuggy Event (SOC calculation GB-22 based on 25-kt yield). 


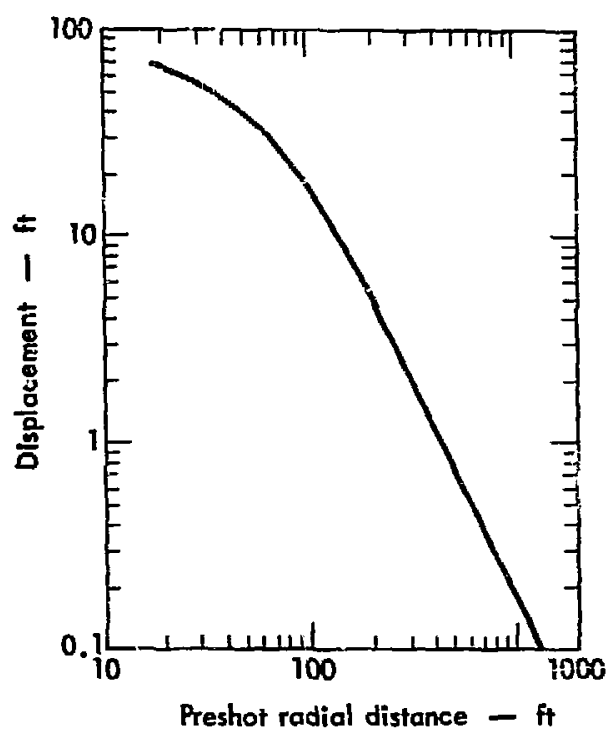

Fig. 4. Permanent displacement of rock surrounding the Gasbuggy shot point (SOC calculation GB-22 based on 25-kt yield): displacement vs preshot radial distance. those required to cause gross failure in triaxial strength tests; hivever, assuming that failure of shocked rock approximates failure in the laboratory, the stresses are probably sufficien'ty high to produce a small amount of permanent strain in the form of incipient plastic or cataclastic flow. The latter term implies crushing, granulation, or intergranular slip for which friction is irnportant. In the present instance, the high clay-mica content of the matrix material suggests operation of the last-mentioned mechanism.

Information at hand indirates that loading under shock conditions does not exactly parallel that associated with triaxial tests. Specifically, she increase in differential stress $\left(\sigma_{1}-\sigma_{3}\right)$ with increase in mean stress is not as great in the shock experiment. Under these circumstances,

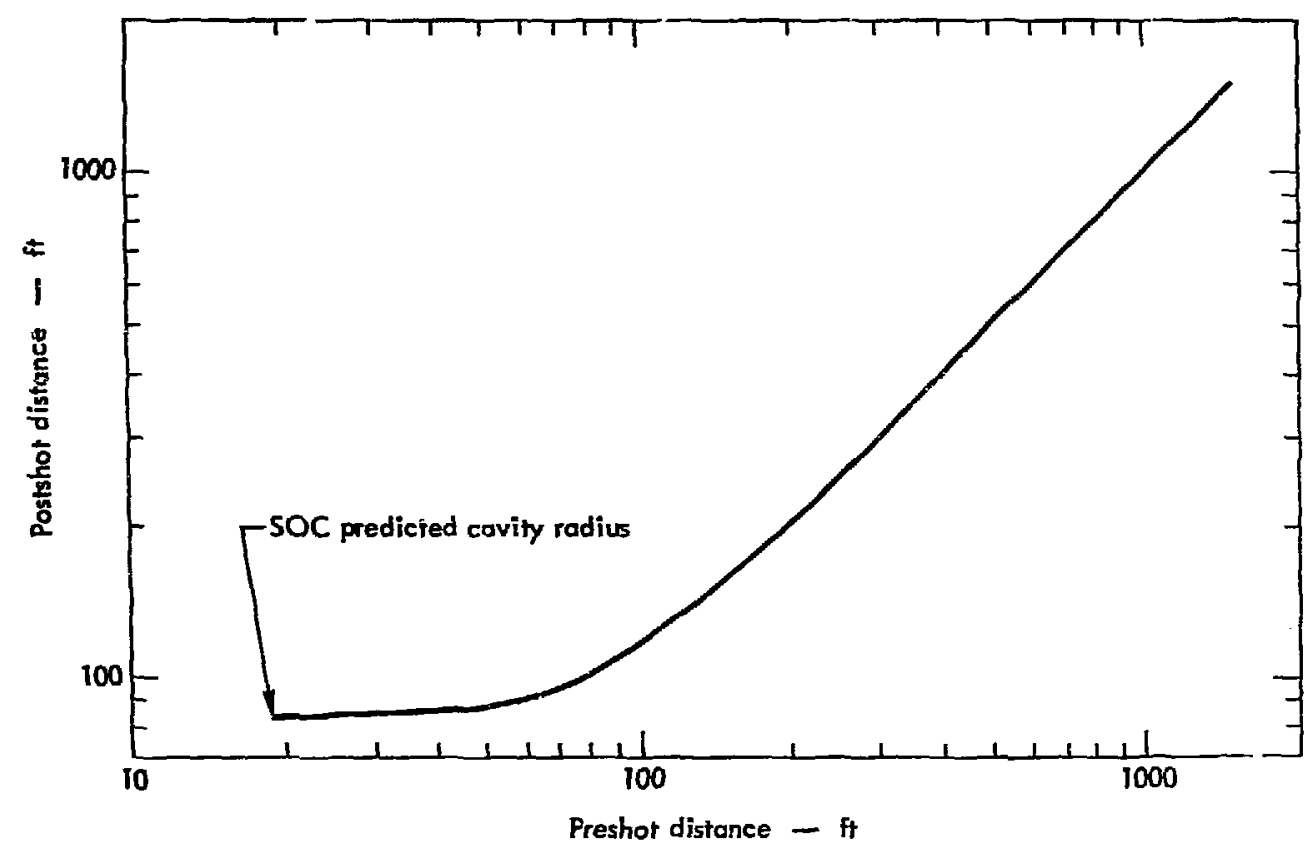

Fig. 5. Permanent displacement of rocks surrounding the Gasiuggy shot point (SOC calculation GB-22 based on 25-kt yield): preshot vs postshot distance. 


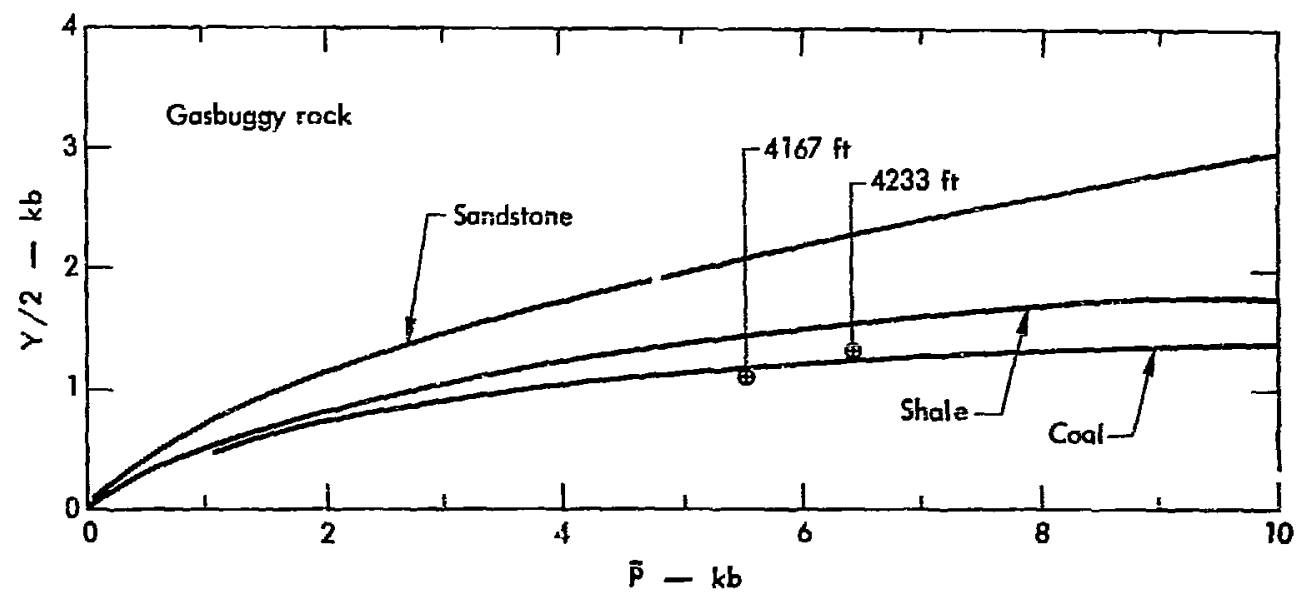

Fig. 6. Strength of Gasbuggy rocks irom triaxial laboratory tests. 7

$$
\mathrm{Y} / 2=\frac{\sigma_{1}-\sigma_{3}}{2} ; \bar{P}=\frac{\sigma_{1}+\sigma_{3}}{2} \text {. }
$$

using compressibility data instead of triaxial tests as a guide, onset of fracturing on loading is assumed to occur at lower stress levels than would be predicted from Fig. 6. The threshold is largely unexplored for most rocks, and fractureradii predictions are weakened by the lack of information on behavior at low stress levels on loading as well as on unloading. In the case of shocked rock, unloading involves simultaneous decrease of both mean and differential stress. Thus, either brittle or ductile-brittle yielding may eventually occur in rock whose ultimate strength was not exceeded by the peak pulse. ${ }^{\neq}$Additional uncertainties in predicting the degree of fracturing as a function of distance from the $W$. $P$, are the as yet unassessed roles played by (1) volume dilation under triaxial compres- sive loading and (2) reiasation phenomena upon passage of a shock wave through porous malerial, where one or more of the stresses can locally become truly tensile. When we add the uncertainties in our knowledge of the pressures generated by the shock to those discussed above concerniris the nature of the response of the rock, we should be circumspect in our treatment of the formation summarized in Figs. 3 through 6.

\footnotetext{
*This type of fainure has been called "tension cracking" in predictions of franture radii, even though all principal stresses are compressive. Fractures so produced are normal to the least of the three compressive stresses and are equivalent to extension fractures of static tests. If one or more of the principal stresses are tensile, i. e., of the opposite sign, fractures produced normal to the least principal stress are called tensile fractures.
} 


\section{Microfracturing}

Standard thin sections $(22$ < $35 \mathrm{~mm})$ of the GB-3 core samples were examined microscopically. Core samples were impregnated with epoxy under vacuum in order to minimize fracturing during the subsequent sectioning and grinoing process. All sections were parallel to the core axis and hence approximately normal to the bedding of the Gasbuggy rocks. In the descriptions that fol!ow, fracturing implies recognizable loss of cohesion irrespective of the rature of the break. The questions addressed by the examination are: How extensive is the fracturing or a microscopic scale? Ace lractures through-going, i.e., once initiated, are breaks propagated across the specimen for any distarice? Is the position of the crack influenced by grain boundaries, mineral cleavages, or other preexisting discontinuities? How does failure in the Lewis shale differ from that of the Picture Ciffs sandstone? Is there any sign of plasticity in the ubiquitous carbonate minerals of the sediments?

\section{MINNERALOGY}

A summary of the mineralogy and petrology at the Gasbuggy site has been prepared by J. E. Fassett, USGS (see Ref. 6) and by L. D. Ramspott ${ }^{10}$ from GB-1 preshot core samples. Results of quantitative $x$-ray analysis of weight percent of three constituents, quartz, calcite, and dolomite, are ${ }^{8}$ : Picture Cliff sandstene (P-43, 3970-ft depth) $54,1.3$, and $5 \%$; $(P-24,4095-\mathrm{ft}$ depth $)-$ 56 , <1, and $<1 n_{t} ;(P-47,3946-\mathrm{ft}$ depth) $-65,<1$, and $<1 w_{n}$ ); Lewis shale
(4218 to $4280-$ ft deptr, av 14 samples) 5 ', 3, arid $7 "$. The remainder of the rocks consist, of feldspar and fine-grained minerals stich as micas and clays. The important observation related to failure is the high proportion of mechanically weak minerals (micas, clays, and caicite) in both rock types. They comprise an estimated 15 to $25 \%$ by volume of the Picture Cliffs sanstone and 25 to $30 \%$ of the Lewis shale. Phi tomicrographs of the rocks show the individual quartz and feldspar grains floating in the matrix. Quartzquartz or quartz-feldspar grain contacts, which are potential sites of local itress concentration on loading, are rare. $\mathrm{Dy}$ contrast, the Ojo Alsmo sandstone has a lower proportion of matrix material and consequently a larger number of such contacts within a given volume.

\section{DEGREE OF FRACTURING}

A microscopic survey of the samples indicates a low level of matrix fracturing. The most highly fractured samples examined come from the Ojo Alamo, 650 to $750 \mathrm{ft}$ from the W. P. Several samples of the Picture Cliffs sandstone are virtually uniractured. In these, the quartz and feldspar grains are clear and unbroken; no dilation is visible on the bedding or at grain boundaries, even at the highest magnifications. In order to compare the degree of fracturing in the various samples, a semiquantitative scale was arbitrarily set. Four degrees of matrix fracturing were recognized: moderate, low-moderate, low, and no fracturing. Examples from the sandstone studied are shown in Fig. 7. 


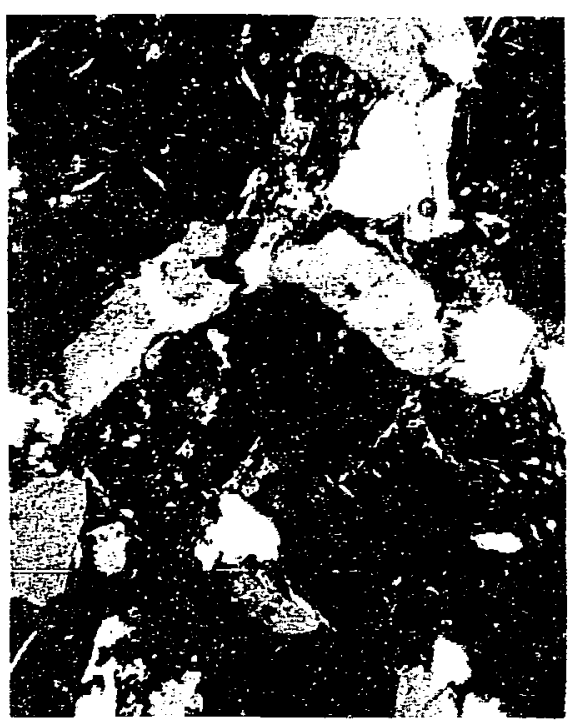

(a)

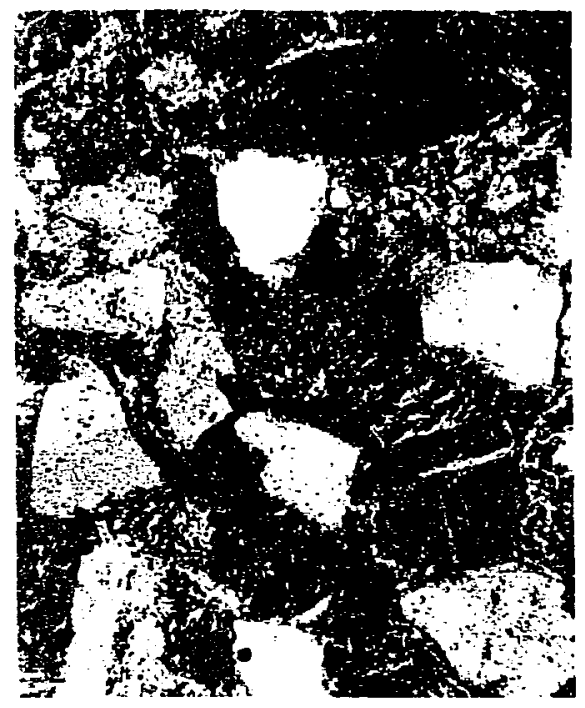

(c)

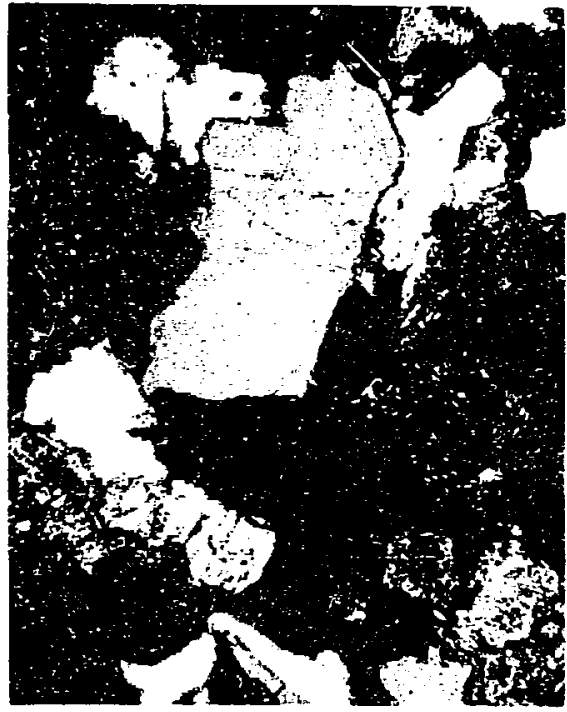

(b)

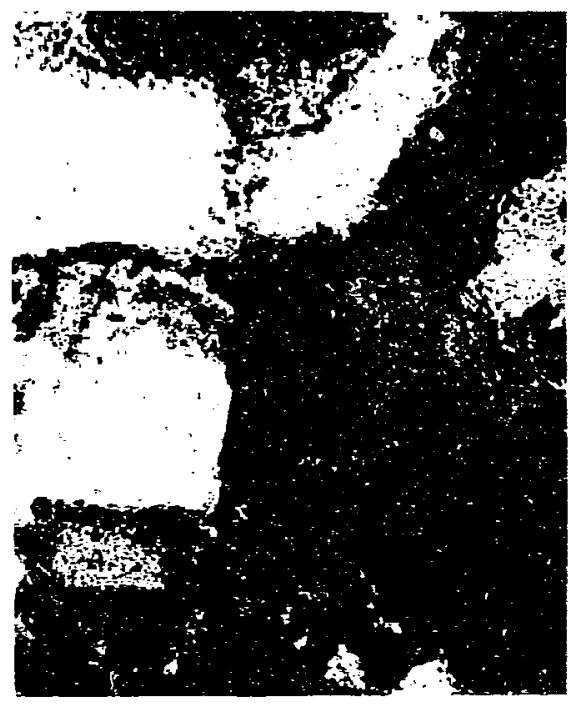

(d)

Fig. 7. Degrees of matrix fracturing in postshot Gasbuggy core GB-3: (a) moderate Ojo Alamo sandstone (3509 it SHD); (b) low-moderate-Ojo Alamo sandstone (3618 ft SHD); (c) low - Picture Cliffs sandstone (4167.8 ft SHD); (d) none Picture Cliffs sandstone $(4167.3 \mathrm{ft}$ SHD). Scale bar $=100 \mu$. Doubly polarized light. 
The samples have been assigned to one of these sategories on the basis of the overall amount of iracturing observed (refer to Table 2). There does not seem to be 2 correlation between radial distance and degree of fracturing in the samples examined. However, this may in part reflect the selectivity in the initial sampling. In general, highly f-actured core is not recovered; moreover, any study involving additional specimen preparatien (cutting or recoring) fosters unconscious selection of coherent core samples.

Permeabilities measured in core samples at 1 atm and macrofracture counts along the core length are included in Table 2. ${ }^{6}$ These show little correlation to each other; however, the permeability measurements do correlate well with the assessment of microfracturing in this study. The order of increased amount of macrofracturing is the same as the order of increased permeability irrespective of distance from the $W$. P.

\section{NATURE OF THE FRACTURES}

Healed, preexisting fractures can be distinguished from fresh shock-induced fractures on the basis of the discoloration, precipitation, or alteration typically seen along the former. Preexisting fractures are nct conspicuous in the core samples, and there is no convincing evidence that shock-induced fracturing preferentially sccurs parallel to them.

Typically, the fractures in the coarsegrained sandstone are "short lived," i.e., they fail to traverse a single grain or grain boundaries. As the overall amount of fracturing increases, they tend to be individually longer and extend across several large grains if these are contiguous (see Fig. 7(a)). Commonly the subangular quartz and feldspar grains are surrounded by weaker clay and micaceous minerals. In this case, through-going fractures in quartz die out in the matrix (refer to Fig. 9(d)).

Separation at grain boundaries in the coarse-grained sandstones is rare; however, as the grain size becomes finer, e.g., in siltstones of the Kirtland and Lewis formation, dilation or partings parallel to bedding become more conspicuous (see Fig. 8). In some cases, the through-going partings are parallel to local compositional inhomogeneities that transgress the normally flat bedding. They vary in width from 1 to $50 \mu$ in the samples studied. The broadest parting shown in $\mathrm{Fi}_{\bar{\sigma}} .8(\mathrm{a})$ is $33 \mu$ wide; Fig. 8(c) shows one $7 \mu$ wide. These breaks have the character of strictly extension (or tension) phenomena, as they are open; they characteristically follow grain boundaries, and they have propagated without involving the fracture of the larger grains of quartz and feldspar in the sample. Samples showing dilation are noted in Table 2.

\section{BEHAVIOR OF OTIER MINERAL COMPONENTS}

Evidence of plasticity in the form of kinking in the coarser micaceous materials and mechanical twinning in calcite is infrequently observed in the suite of rocks. No mechanical twinning at all was seen in dolomite, the more abundant of the two carbonate minerals, as might be expected from the higher resolved shear-stress, $\tau_{c}$, necessary to initiate it $(2000$ bars in dolomite vs 30 to 60 bars in calcite, at 


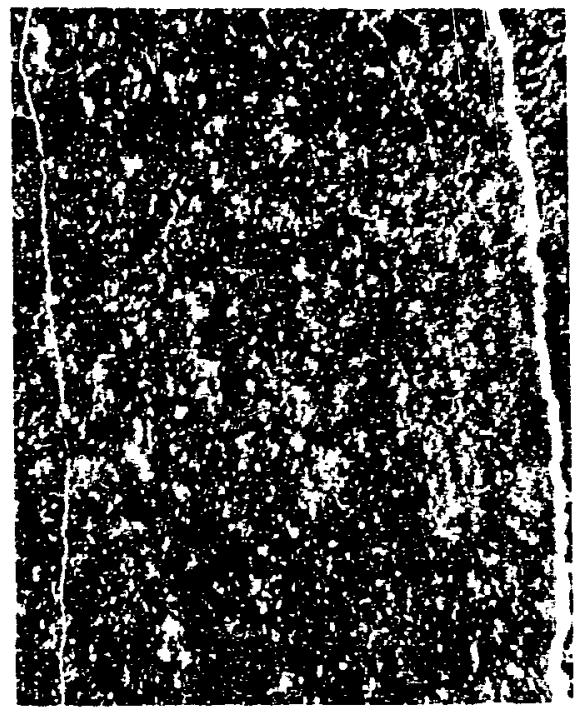

(a)

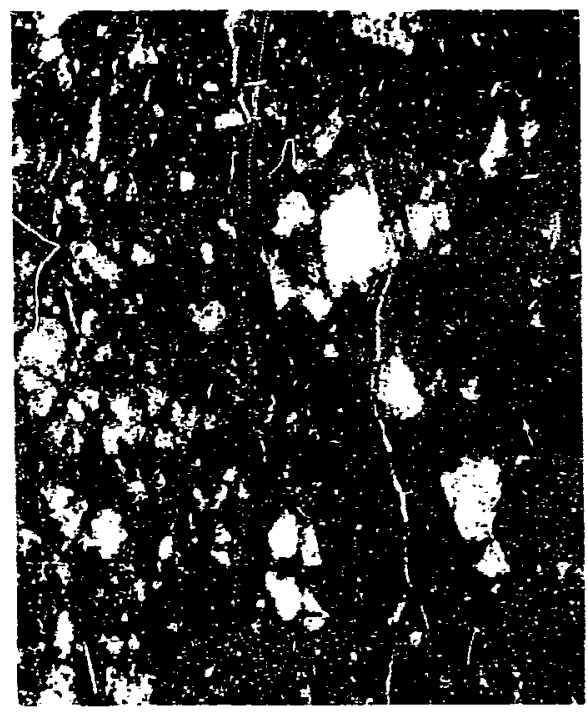

(b)

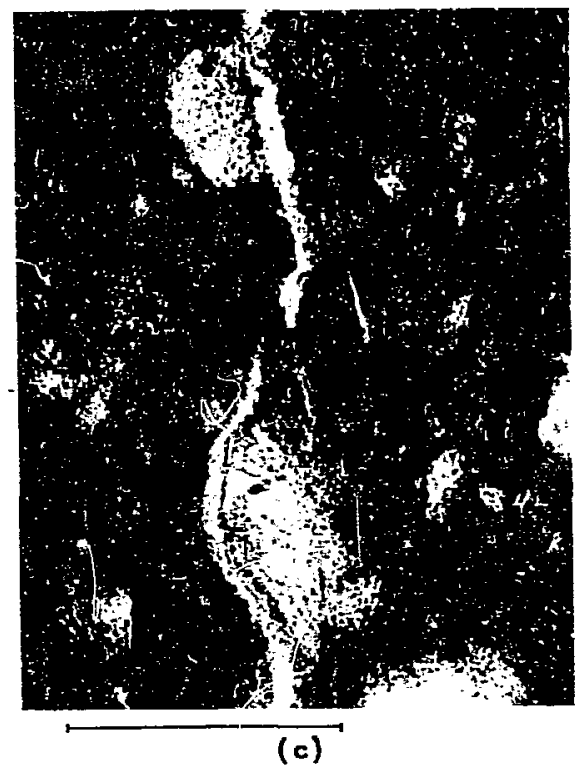

Fig. 8. Dilation in postshot Lewis shale: (a) open partings (up to $33 \mu$ ) parallel to bedding (4574 ft SHD); (b) and (c) position of partings in the matrix $(7 \mu$ ) with respect to coarse-grained components $(4503 \mathrm{ft}$ SHD). Scale bar $=100 \%$ Bedding vertical. Dounly polarized light. 


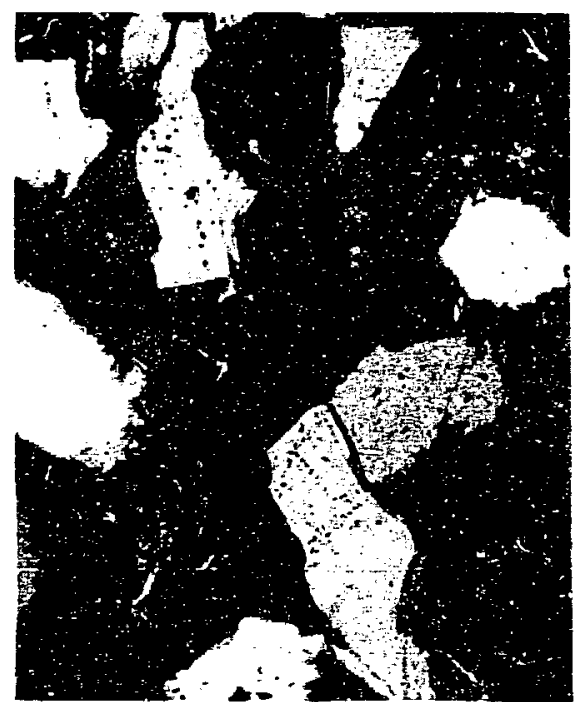

(o)

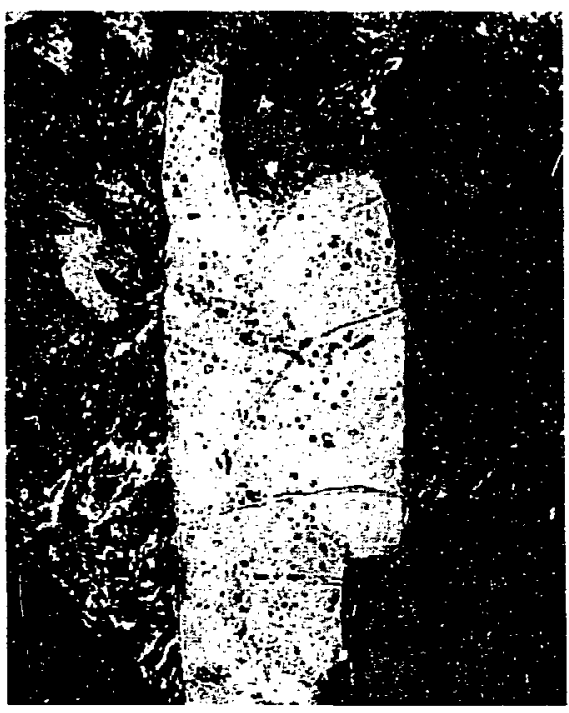

(c)

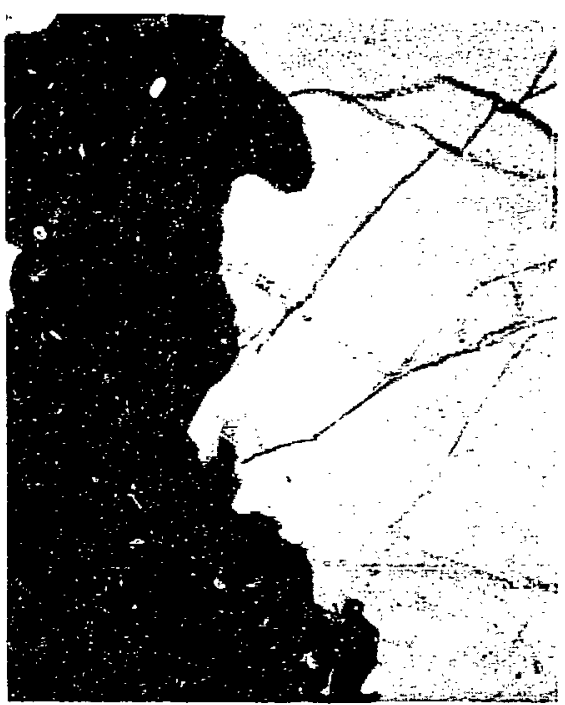

(b)

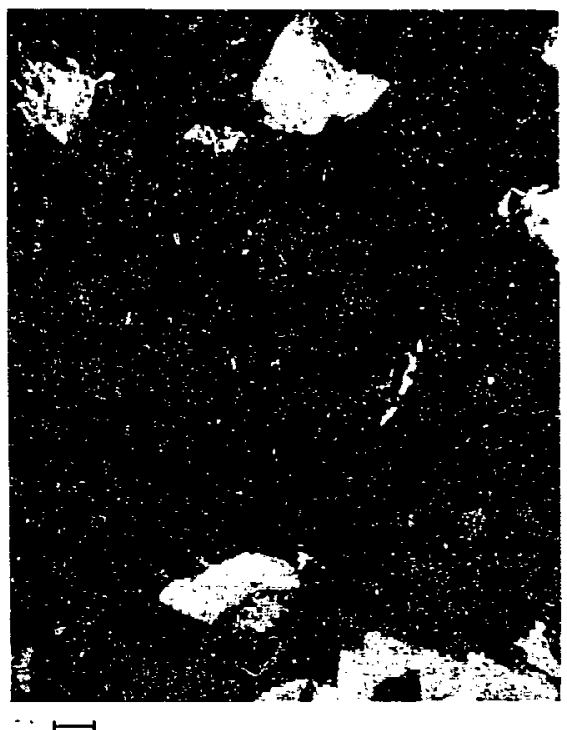

(d)

Fig. 9. Comparison o: behavior of Picture Cliffs sandstone and Piledriver granodiorite at comparable peak radial stresses: (a) Picture Cliffs sandstone $(3915 \mathrm{ft}$ SHD) - 2.3 kb; (b) Piledriver granodiorite (BL-225-2) - $2.6 \mathrm{~kb}$; (c) Picture Clifffs sandstone (4167.8 ft SHD) - 6.6 kb; (d) Piledriver granodiorite (P-2-60) $7.1 \mathrm{~kb}$. Scale bar $=100 \mu$. Doubly polarized light. 
temperatures below $400^{\circ} \mathrm{C}$ and a 5 - $\mathrm{kb}$ confining pressure ${ }^{11}$ ). In some specimens, cleavages in the carbonates are more conspicuous than in comparable unshocked GB-1 core; however, the effect on permeability is insignificant.

\section{COMPARISON WITH BEHAVIOR OF GRANODIORITE AT COMPARABLE STRESSES}

The observations suggest that failure of these sedimentary rocks at low nean pressures is transitional, as opposed to purely brittle or ductile failure. The strength or yield point is equated with the onset of appreciable cataclastic flow in the matrix cement and with some as yet unknown amount of tracturing of the brittle components. In order to emphasize the difference in behavior of two materials that have undergone transitional and purely brittle failure, photomicrographs of the Picture Cliffs sandstone are juxtaposed with those of the shocked Piledriver granodiorite (see Fig. 9). Peak radial stresses seen by the two types of rocks $(2.3$ and $2.6 \mathrm{~kb}$, and 6.6 and $7.1 \mathrm{~kb}$, as shown in Fig. 9) are comparable. Clearly the fracturing is more extensive and the cracks are wider in the granodiorite. Specimen preparation was identical for bơti rock types. Fractures in the Gasiuggy sandstone would not be seen in photomicrographs taken at the same (lower) magnification as used for the granodiorite. A conscious effort was made to photograph representative portions of the thin sections, rather than highly fractured sectors, in the case of the granodiorite and lightly fractured sectors of the sandstones.

\section{Discussion}

The most impressive feature of the rocks examined is the generally low degree of fracturing. This is consistent with the preliminary data on the changes in permeability produced by the explosion on these samples $3,12,13$; nowever, it is difficult to reconcile this finding with the observations and calculations that led to statements such as "This region of the reservoir evidently was intensely fractured to at least $375 \mathrm{ft}$ from the shot. Similar evidence plus gas production data indicate that intense fracturing took place in the Lewis formation to at least $400 \mathrm{ft}{ }^{114}$ These conclusions stemmed primarily from examination of caliper logs of postshot holes and from the positions of casing and cliper cable breaks. Moreover, pre- shot SOC calculations (predictions) seemed to be consistent with such an interpretation, ${ }^{4,9}$ since "tensile cracking" was anticipated tc extend beyond the limit for compressive failure, which is now estimated to be approximately $60 \mathrm{~m}$ from the W. $P{ }^{7}$ In view of the absence of pervasive microf racturing 60 to $80 \mathrm{~m}$ from the shot point, distant failure in cables, etc., would appear to be due to extension or tensile failure associated with collapse or dilations - perhaps aleng preexisting discontinuities such as bedding. Closer in, within the Picture Cliffs sandstone located 60 to $70 \mathrm{~m}$ from the shot point, cumpressive stresses were not sufficient to cause brittle failure of the matrix. This is not to say that the rock did not yield under the 
applied load, ur during unloading, but that the deformation mode was largely flow with incipient fracture. The behavior of the rock at low stress levels in laboratory tests is not sufficiently well known to have predicted the results. From the standpoint of increased gas production, this portion of the behavior history of a deformed rock is of greatest interest since the volume of surviving rock that has been subjected to low mean stresses is several times the volume that sees mean stresses greater than $10 \mathrm{~kb}$.

Volume expansion on loading or unloading (dilation), plays a role in deformation that has not been assessed in either laboratory or field experiments. The results of dilation are most evident in finegrained nembers of the suite of postshot rocks exarnined, the Lewis shale and the Kirtland siltstones. At 1 atm confining pressure, there are wide (>33 $\mu$ ), "longlived" openings parallel the bedding planes and boundaries of compositional changes. At overburden pressures of $0.3 \mathrm{kh}$, they are probably closed, and their effeet on the permeability may be small. Moreover, minor adjustinents in the positions of the very-fine-grained clay and micaceous matrix minerals, as well as chemical cementing processes, may roseal the breaks within a few years.

\section{Acknowledgmerts}

1 am indebted to the El Paso Natural Gas Company for supplying the postshot core and unpublished information relevant to its makeup, fracturing, and permeability. Leo Rogers of that organization and $\mathrm{J}$. Korver selected the samples. John Rambo ran the GORBAG code that calculated the position of the core samples with respect to the shot point. Many at LRL have devoted their time and talents to the evaluation of the data presented. They include A. Holzer, J. T. Cherry, R. Quong, H. Heard, Don Emerson, and A. Lewis. 


\section{References}

1. A. Holzer, Gasbuggy Preshot Summary Report, Lawrence Radiation Laboratory, Liverınore, Rept. UCRL-50345 (1967).

2. A. Holzer, Gasbuggy Preliminary Postshot Summary Report, Lawrence Radiation Laboratory, Livermore, Fept. UCRL-50386 (IS68).

3. A. Holzer, Gasbuggy in Perspective, Lawrence Radiation Laboratory, Livermore, Répt. UCRL-7દ175 (1970); Proc. ANS Topical. Meeting, Engineering with Nuclear Explosives, Las Vegas, Nevada, January 14, 1970.

4. D. E. Rawson, J. A. Korver, R. L. Pritchard, and W. Martin, Postshot Geologic Investigations - Froject Gasbuggy, Lawrence Radiation Laboratory, Livermore, Rept. UCRL-71354 (1968).

5. J. A. Korver and D. E. Rawson, Gasbuggy Postshot lnvestigations in GB-ER, I-awrence Radiation Laboratory, Livermore, Rept. UCRL-50425 (1968).

6. J. R. Shaughnessy, H. Butcher, and C. F. Brown, Core Descriptions and Observations of the Postshot Cores from GB-3, El Paso Natural Gas Company Repori (1969).

7. J. T. Cherry and F. L. Peterson, Numerical Simulation of Stress Wave Propagation from Underground Nuclear Explosions, Lawrence Radiation Laboratory, Livermore, Rept. UCRL-72216 (1970); Proc. ANS Topical Meeting, Engineering with Nuclear Explosives, Las Vegas, Nevada, January 1970.

8. R. Braun, L. Ramspott, and W. Wadleigh, Quantitative Mineralogy of Preshot Gasbuggy Samples, Lawrence Radiation Laboratory, Livermore, Rept. UOPKK 70-20 (1970).

9. J. T. Cherry, D. B. Larson, and E, G, Rapp, Computer Calculations of the Gasbuggy Event, Lawrence Radiation Laboratory, Livermore, Rept, UCRL-50419 (1968).

10. L. D. Ramspott, Gasbuggy Petrography, Lawrence Radiation Laboratory, Livermore, Rept, UOPKK 68-25 (1968).

11. D. V. Higgs and J. Handin,"Experimental Deformation of Dolomite Single Crystals," Bull. Geol. Soc. Am., 70, 245 (1959).

12. R. Quong et al., Permeability of Picture Cliffs Sandstone, Gasbuggy Site, Lawrence Radiation Laboratory, Livermore, PMD Note No, 291.

13. R. Quong, personal communication (1970). 


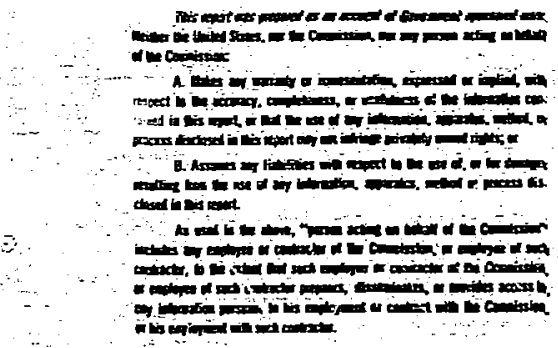

Printed in USA. Available from:

Clearinghouse for Federal Scientific and Technical Information National Bureau of Standards, U. S. Department of Commerce Springfield, Virginia 22151

Price:-Printed Copy 53; 00; Microfiche s0.65. 